\title{
Katrina, Cronulla Beach and France on Fire: An Anti-Colonial Critique of Empire in 2006
}

\author{
A Dialogue with \\ George Sefa Dei \\ Ontario Institute for Studies in Education of the University of Toronto \\ Email: gdei@oise.utoronto.ca \\ \& \\ Arlo Kempf \\ Ontario Institute for Studies in Education of the University of Toronto \\ Email: akempf@oise.utoronto.ca
}

\begin{abstract}
With a focus on both the theoretical and practical implications of anti-colonial theory, this article discusses a number of conflicts that have brought the oppression of marginalized bodies to the forefront of mainstream media attention. The authors formulate an anti-colonial response to the human-made disasters in the Southern United States, France and Australia. While race is finally being taken up in the mainstream media with regard to these events, such coverage has largely involved strategic denials, powerful silences and re-invocations of dominant colonial and racial paradigms. The anti-colonial discursive framework looks to the voices of the oppressed and to the various forms of, and potentialities for, agency and resistance to guide its response to the social and discursive disasters discussed herein. Given the prominence of 'post' discourses in the academy, a resuscitation of the anti-colonial discourse is necessary in order to provoke actionoriented resistance-based responses to modern colonial practices.
\end{abstract}

\section{Introduction}

Professor George Sefa Dei has written and taught extensively in the fields of anti-colonialism and anti-racism. His latest work on the subject is Anti-Colonialism and Education: The Politics of Resistance, co-edited with Arlo Kempf for Sense Publishers (2006). Dei and Kempf are also co-authoring a forthcoming volume on anti-colonial theory. Arlo Kempf works in the areas of anti-colonial historiography and anti-racism in education. Their interest in anti-colonial politics influenced and shaped this intellectual project. The following dialogue was recorded in January of 2006, in Toronto, Canada. The motivation for the conversation arose out of a desire to develop and extend the anti-colonial discourse as articulated by various African and Latin American anticolonial thinkers, to and for a contemporary context. Given the prominence of 'post' discourses in the academy, a resuscitation of the anti-colonial discourse is necessary in order to provoke action-oriented, resistance-based responses to modern colonial practices. A contemporary articulation of the anti-colonial discourse allows for a nuanced rendition and reading of colonizing relations. The focus on agency and resistance, which together lay at the heart of anticolonialism, is particularly relevant as people everywhere struggle with and through, the internal

Journal of Contemporary Issues in Education, 2006, 1(2), pp. 4-25.

ISSN 1718-4770 C 2006 University of Alberta

http://ojs.educ.ualberta.ca/index.php/jcie/ 
and external processes of colonization. We are living in a time of empire. Nothing can be gained by remaining silent on this issue. For the most part, their conversation is presented verbatim.

\section{Section One-Anti-Colonialism, Knowledge and Resistance}

Arlo Kempf: In earlier work, you have defined 'colonial' broadly, as: anything which is imposed and dominating (see Dei, 2000; and Dei and Asgharzadeh, 2001).

George Sefa Dei: Right.

A: Could you discuss how this definition departs from previous conceptions of the same term?

G: I think, first of all, we should clarify the terms 'imposed' and 'dominating.' These terms are used to speak to the complexities of colonial and neo-colonial relations. We cannot simply see such relations in terms of north vs. south or foreign vs. alien. We have to look at the way these relations and dynamics of power play out internally as well as externally. So if your concern is how this definition differs from the contemporary or existing one, then I think it brings a sophistication, specifically as it relates to fixing our gaze on the internal dynamics of colonial relations. It's not simply a case of looking at external forces then, but analyzing class, gender, sexuality, and other sites of internal power relations.

A: We must look then from the international, to the national, to the regional and to the local - to communities and microanalyses. A great many things are imposed upon us at myriad levels. Do we see just any oppression as colonial oppression?

G: I think all oppressions have colonizing tendencies. So when we look at oppression, we have to look at power, which is very central within the whole notion of colonization. Looking at power within oppressive relations teases out the colonial (or colonizing) elements of oppression. So I think, in this case, I would say yes to your question. All oppression is colonizing if we look at the power dynamics of oppressive relations. I cannot think of any oppressive relations that are not colonizing.

A: So, anti-colonialism, as it departs from ideas of post-colonialism, challenges the idea that the colonial encounter has ended. In other words, anti-colonialism takes issue with the etymological implications of the 'post' in post-colonialism. Other than the argument that colonialism continues, what distinguishes the post-colonial from the anti-colonial? If possible, can you address the notion of resistance here?

G: Right, yeah. That's a good question. With reference to the post-colonial, we have to be careful not to imply 'after.' We need to look at it with more sophistication than many so-called post-colonial scholars have, and be careful not to skirt issues of complexity.

A: It's not a simple divide though; anti-colonialism works with certain articulations within postcolonialism, but not all.

G: Right. What to me distinguishes the anti-colonial, as we talk about it today, are the core notions of indigeneity, and as you mention, resistance. Anti-colonialism works with local understandings of colonial relations. Colonial relations work both internally and externally. Beyond that, anti-colonialism looks at both the material and non-material aspects of colonizing relations. It's not just simply the imposition of the material but also questions of the nonmaterial, the spiritual dimensions of the colonial encounter. An anti-colonial approach must also speak to the local modes of resistance that are taking place, which are sometimes denied. Within all colonial encounters, we see that several groups of people are being colonized. We have to look at the local forms of resistance within all of these groups. Anti-colonial struggles work with a long conception of time and depth - history, history, history! 
A: Right, and agency. We have to look at organic resistance and the local possibilities for that resistance.

G: You're right, agency is key. Anti-colonialism is also about putting that agency into practice to ensure transformation.

A: So, I wonder about some of the romanticization that comes along with post-coloniality. On more than one occasion I've told people I was working with anti-colonialism and had them respond, "Oh post-colonialism, sounds wonderful." People seem to read 'post' in place of 'anti.' While there is a lingering attraction to notions of post-coloniality, there is a reluctance to take up the strategic, political and practical elements of anti-colonialism; spheres that some people read as outside of the academy. So I see anti-colonialism as a strategic action-oriented reappropriation of the continuing neo-colonial struggle.

G: I think this fact is very crucial. Within the 'post-colonial,' we talk about the ambiguities, the ambivalences, the tensions, the contradictions, and while these are important, they are not new. These have always been themes within colonizing relations. How can we think of resistance without talking about the tensions, contradictions and ambivalences? But what the anti-colonial does differently, is talk about the implications of these tensions, contradictions and ambivalences in terms of the past present and future. I'm talking about the notion of implication in the sense of how we understand colonizing relations as on going and self-implicating. For instance, we must understand that certain subjects within the colonized order can actually participate in the process of colonization. And as you say, there is some romanticization of post-coloniality, which potentially implies that the oppressor, or colonizer, is somehow ambiguous, or worse, unnamable. Some post-colonialists of course, will dispute this.

A: Exactly. In this way the tension becomes the subject rather than the indigenous resolution of that solution. Colonized and colonizing bodies alike, become part of a narrative - part of the same struggle - a binary at best. The ultimate subjectification of the colonized body comes about when she is othered in both her own epoch, and in the historical understanding of that epoch and her role therein.

G: Right, and what is very important here is that we identify the colonizer here, and the spaces she occupies.

A: You have to name it, though. You have to name it at all times, even if the colonizer is in fact the colonized, in other spaces at other times.

G: Exactly. It cannot always be fluid and in flux though. It cannot permanently be in this 'space' of transference; it cannot be something that is simply metaphorical.

A: So then, anti-colonialism might depart from post-colonialism right about the time that postcolonialism starts to work with post-modernism, maybe, as far as the ambiguities, and the dangers of identity politics and fluidity.

G: Yeah. Let us remember however that when we talk of this whole discourse of modernity and post-modernity, it's very problematic to talk about a face or phase of modernity that we can label as fixed and/or clearly delineated. That, to me, is something that we need to bring up when we talk about anti-colonialism. I mean, what is the pre-modern? No one has the right to name anything as such.

A: We have to interrogate our ideas of modernity, as well as our ideas of post-modernity. Since it's a discourse that's always shifting, it's important to look at the grounded implications of discourse and politics. 
G: Yeah, and what you see now is that when we talk about modernity, we deny some groups status within that notion of modernity - allowing space only through certain juxtapositions with other times and peoples.

\section{Section Two - The Self, Other and Embodied Knowledge}

A: So it makes post-modernity the only option for certain bodies. Well, if we see decolonization as a response to anti-colonialism, as both social and individual processes within the anti-colonial framework, how do educators and learners develop a critical understanding of the relations of the self and of the other? Further, how do they then begin to bridge the gulf between individuals and groups by revealing both colonizers and colonized as affected and disaffected by the colonial encounter?

G: First of all, there's a connection between the self and the other. I mean, there are a number of theories: Dubois (1997), a long time ago, talked about the relations between the self and the outside world.

A: And Fanon (1969) more recently, with his notions of recognition in Black Skin, White Masks. G: Right, there's that relational component, but to me it's more than that. We also have to look at it in terms of the ways in which the body comes to know itself. I think the body can know itself without the presence of the other. There is a rootedness of knowledge in the body and this is what we mean when we talk about embodied knowing and knowledge. Part of the process of decolonization is being able to work with embodied knowledge. This is to say not just simply decolonizing the mind or engaging the project of trying to subvert colonial relations, but also working with embodied knowledge to identify how we come to know ourselves and how we evoke agency. This is crucial for connecting individual resistance to group resistance.

A: So, can we say that working with embodied knowledge in a resistance position is a step towards decolonization within the anti-colonial framework?

G: Yes, I think this is why education is crucial. For example when you look at school systems, notions of cultural affirmation and reinforcement are crucial. I think people have to know themselves. In order to be able to address all the problems that confront us, we have to know our relation with the other of course; but we also have to know ourselves: who we are, our place in the human community, our sense of purpose and our sense of worth. We must engage local solutions, but this necessity is rendered impossible if we cannot talk of local creativity and resourcefulness. If people do not start from where they are, they cannot come to know themselves, their place in the world, their place in history or their responsibilities. No one lives in a bubble. Those around us shape our world, just as we can sometimes shape the world surrounding us. This speaks to the importance of understanding self and the environment, and of engaging in politics on the basis of that knowledge. Identity is not just a political concept, but also a political act. To claim an identity is to commit a political act. This is why a shift is needed from talking about identity to talking about identifications. It's important to talk about identifications in terms of what motivates people's identifications at a particular moment.

Having said this, I believe that there are limitations to situational politics, or politics of the moment. We at times seem to be floating in space and not grounded in any way. We have to remain connected to a political project that is broader than the individual location with which we are identifying.

A: So, is that a danger then? I'm just thinking about coalition building in the educational context: we teach students of different ages to identify with their own embodied knowledge and 
to see where they're coming from. So before they start to totally define themselves by virtue of their oppression, or participation in the oppression of others, they must try to get a more objective sense of themselves; try to get a sense of who they are and what embodied knowledge they have. If that's the case, are there dangers or limits to coalition building resulting from that sort of self engagement? Spivak (1999) and others have discussed and critiqued notions of strategic essentialism and we know this is a controversial idea. Should we be concerned with these limitations or should we focus instead on the new possibilities emerging from such engagement?

G: No, I think it's more important to look at new possibilities here, and I'll give you an example: when I talk about knowing oneself, there are certain teachings for example, that are not presented to the individual in relation to others around her. Such teachings are presented in terms of one's understanding of one's place in a particular environment, which of course carries an association to the land. So that knowledge is acquired through interacting with one's location and how one comes to assign location. That becomes the starting point. When we talk about coalition building, we all come to coalitions from different standpoints, with different histories and with different experiences. We work to see connections however; such as the ways our histories are contingent upon one another. We see the ways they are connected and we look for the possibilities for mutual inclusion in our respective histories.

A: Yes, we develop a dialogue with and within our histories. We work back in order to work forward.

G: Potentially. We can come to mutual understandings of where we are coming from. From there we draw connections with each other, and are able to work with and towards strategic location.

A: Right, without denying the inequities and power imbalances through which we arrive at this hypothetical table of mutual recognition and understanding. Meaning we cannot deny difference. G: Right, exactly. This is particularly when we talk about the whole notion of solidarity with indigenous social movements. As someone who also writes on anti-racism and the reconfiguration of resistance, I'm interested in engaging in social movement politics in ways that allow us to foreground certain issues at a given moment in time.

\section{Section Three - Empire Imperiled: Iraq and Katrina}

A: Anti-colonialism stands on the shoulders of a powerful body of work - among this work is the scholarship of African anti-colonial scholars. Albert Memmi's (1969) work brilliantly elucidates the portrait of colonizer and colonized. He explains the dynamic and sometimes overlapping relation between the two. In the context of the current U.S. colonial project, the illegal invasions and occupations of Iraq and Afghanistan for example, who are the colonized and who are the colonizers? This of course seems clear cut, but we must consider as you say, the internal epistemological elements of colonization and the American soldier. I have two cousins in the US military. For them, military service was inspired by financial necessity and only thereafter justified by the epistemic hatred and denial required to execute their murderous assignment of empire building. The world's greatest fighting force comprises the nation's most oppressed bodies - this is the poverty draft - the race draft. Rich Whites are a no show on the ground in Bush's so called war on terror. So while the colonial encounter has both internal and external dimensions, it also has numerous disparate sites. Many Americans of color find themselves in the role of occupier due to stateside oppression. How do we sort this out? 
G: Yeah, and I think this is where sometimes we raise these questions of anti-colonial versus post-colonial. Unfortunately, Memmi's brilliant work is sometimes reduced to a simplistic critique structured around the colonizer/colonized binary. I think on one level, if you ask the question, who are the colonizers and who are the colonized - this to me is very obvious. The empire becomes the colonizer. Those who use force become the colonizer. We also know however, that local soldiers in some cases aid the invading force, so it makes it a bit complex. We cannot succumb to the somewhat post-colonial idea however, that we don't know who the colonizer is anymore. I think we have to look at it in terms of a history that brings certain bodies to places. In this case, we know who the colonizer is, it is the empire, the invading force, but we also know that there is resistance among the local subjects, alongside the very problematic, local compliance.

A: If we read history with an eye for what brings certain bodies to certain places, the Black man's presence in Iraq can be read differently than the White woman's. Do certain bodies have a greater responsibility than others to not be in Iraq? I don't know if I'm comfortable with that. It implies varied levels of culpability among members of the imperialist US army.

G: Maybe, but by the same token I think it is safe to say the empire becomes the invading force, and is the colonizer. However within the empire itself there are subjects who, if they criticize what the state is doing, help to flesh out some of the complexities that exist around the relation of the empire to the colonizer as an individual. This does not absolve any individual invader however. There are always those who resist, and we must not forget that, particularly because resistance goes unrewarded most of the time.

A: I don't know if possession of greater troop numbers, material resources or superior artillery makes the US occupation of Iraq a cut and dried case of David and Goliath. I know people who enlisted to avoid homelessness. From place to place, context to context, determinates vary. Anticolonialism must act, or work, or be theorized for and in multiple settings - and for multiple spaces within those settings. There seems to arise a complexity or duality in that many Canadians and Americans occupy more than one space in the colonial project. Edward Said (1993) argues that we're never one thing. It begs the question though, how do we work with such complexities? I see this as something different from the idea of hybridity; it's a duality, so looking at the recent racial violence in the wake of Hurricane Katrina, for example, how do such complexities come into play?

G: That's a good question. I think, when we look at Katrina through an anti-colonial prism, we engage in an intersectional analysis of various categories of oppression: race, class, ability, gender, ethnicity and so on. I think such analysis is strengthened by being able to work with the saliency of a particular site of oppression in a particular moment. So what is the example in Katrina? Well, definitely there is a class issue involved, there is a racial issue involved, and to some extent there is a gender issue involved. We know that we can engage any of these issues but never at the expense of any of the others. For example, we cannot say simply that this was a class issue and this had nothing to do with race. We have to know where we are coming from and understand the politics involved when we make such statements. The argument that class and not race is at issue regarding Katrina has been a common refrain in media circles.

A: So when Jon Bon Jovi, at the moment of handing over a one million dollar cheque to Oprah Winfrey for Katrina relief, says, "this isn't a race issue, it's a class issue and it's American people that we have to help," we have to inquire as to the motivations for such inquiries ("Bon Jovi," 2005). 
G: Exactly. It is very important to recognize the fact that there are certain issues that people don't want to bring up. We then have to speak about saliency. It becomes a politically strategic move to speak on saliency without placing oppression in a hierarchy. We are what we are however, and human beings tend to gloss over things that fall outside of their field of vision, or experience. We turn a blind eye when it is convenient to do so. There is a tendency to push 'other' agendas under the carpet, so we need to strategically bring inside and onside that which is pushed aside. We need to work with the saliency of local identities when we talk of the anticolonial frame of reference.

A: I think those sorts of human tendencies are strategic. All predilections toward silence or denial are strategic. I think anti-colonialism has to investigate the silences and in the context of Katrina, the silence around race is deafening. There's almost a competition for who's going to win out; the White celebrity class is denying race, and the Black celebrity class is arguing for its significance. I think it's worth mentioning that we don't hear Blacks denying class the same way we've heard Whites denying race. Instead, the argument for race has been inclusive of class. What are the implications of this? This is strategic behavior with profound implications. Between and within colonizers and the colonized there are privileges and punishments afforded to certain bodies.

G: Institutional hybridity is relevant here. I think hybridity has its modes, but I also want to point to one of the limitations: I don't believe we are all cultural hybrids. I don't believe that everything is about hybridity. When I talk about knowing oneself, there are ideally fundamental places or ideas in which one is grounded. It seems we're all supposed to have shifted to a different space.

A: 'A third space.'

G: A third space. Sometimes I see the value of this idea but other times I wonder about the limitations of such theorization. Sure, we can have the third space, but the presence of the third space does not deny the existence of the space that existed prior to that, or the space beyond that. We are not always in that third space, you know.

A: And it shouldn't relegate those characterized by hybridity, to only that third space.

G: That exemplifies the limitations.

A: If we're not careful, the third space becomes a prison away from the first, second space and potential fourth space.

G: Exactly, and it unleashes Fanon's (1969) construction of amputation, where we amputate a part of ourselves. We need to resist that amputation. That amputation, exactly as you say, boxes people into those limited spaces. We need to lay claim to multiple spaces while holding onto where we come from and where we intend to go.

A: How do you lay claim without falling victim to the boxing in, though? I mean it could be partly because you don't control the way your identity is taken up. Informative here are Fanon (1969) and recognition, and W.E.B. Dubois (1997) and second sight; there's always a way in which identity is taken up beyond you, so how do you control what happens to the third space?

G: Well that's why agency and resistance are very important. Anderson (1991) discusses the concept of the 'imagined community.' I don't simply talk about a claim to a physical space, but also the engagement with the notion of fictive imagination because it serves a political purpose. So, having the agency to imagine, engaging in the politics of imagining, affords a particular ability to address a particular problem.

A: So there's a convergence here between Spivaks's (1999) idea of strategic essentialism (meaning working with and being defined by one quality of an individual, group or people) and 
saliency; as an entry point in a particular context. We can talk here then of strategic saliency, taking one or two sites of oppression and working with them; as a particular case may dictate. For instance with Katrina, we must talk about race and class - but not to the exclusion of one or the other.

G: Precisely, the notion of saliency is not meant to exclude any site of oppression or analysis. It is a strategic entry point; so you can talk about race, class and other areas like gender, as well as the intersections of all of these. It's an entry point in the discussion, where you foreground something that is particularly salient in the moment.

A: Yeah, and that speaks to the danger of exclusive discourse. For instance, what is the political strategy involved in statements like: "Katrina is not race, it's class"? We have to look for the motivations behind such statements.

G: I don't have any problem with somebody saying, "this has to do with class, it has to do with race, and it has to do with gender." This is a language of inclusion, which I support. I have a problem when people use multiple places and identities to exclude something or someone. Often in these scenarios, the result is strategic exclusions - often of race. Further, it's important to understand that the misrecognition of identity is just as problematic as the non-recognition of identity (see also May, 1999).

A: Let's move on to contextualizing the notion of empire. What's going on right now? Ten years ago, we didn't have figures like Bush (or the fundamentalist discourses he espouses) dominating so much of the popular press. On April $30^{\text {th }}$, 2004, President Bush was standing on the lawn of the White House with Canadian Prime Minister, Paul Martin. When asked about Canada's position on Iraq, Bush said,

"Canada's doing a lot in Afghanistan, Canada's doing a lot in Haiti, Canada is a contributor to reconstruction in Iraq, and I am grateful to be able to talk to a friend who shares the same goal, which is affecting behavior based upon our values of human rights, human dignity and freedom. We've got no better partner in understanding the power of free societies" (White House, 2004).

Bush goes on to discuss the resistance to the American re-construction of Iraq, saying,

"There's a lot of people in the world who don't believe that people whose skin color may not be the same as ours can be free and self-governing. I reject that. I reject that strongly. I believe that people who practice the Muslim faith can self-govern. I believe that people whose skins $[$ sic] aren't necessarily ah, are a different color than White, can self-govern" (ibid).

So, although these ideas are rarely expressed so blatantly, they certainly seem to underlie the current US re-colonization of parts of the Middle East. How do you read these comments? The US president is implying that Muslim self-governance - non-White self-governance is a crazy idea that just might work - presenting himself as a visionary on the subject, all the while destabilizing Muslim governments in various parts of the world. This is obviously coming from a place that strategically ignores history and contemporary global politics - but how out of step are such remarks? Do they represent a real departure from something or is this just more of the same? 
G: I think more of the same. And I think the point has been missed here. It's not a question of whether or not non-White people are capable of governing themselves. It is a question of the imposition of values that define the agenda.

A: Even a rhetorical consideration of whether or not non-White people can govern themselves contains an implicit devaluation of non-dominant bodies.

G: These leaders are engaged in designing futures for marginalized people. This is the colonizing tendency: for some to design the futures of others. This is what is at stake here. Clearly people have in the past and will in the future, design their futures, regardless of US and Canadian imperialism. The issue here is the discourse of imposition: imposition of governance, economic exploitation and western epistemological commandments. Someone like George Bush reads anything 'non-western' to mean inferior to that which is western. This may be a harsh critique but I feel that way sometimes.

A: I want to problematize the notion that Bush would feel it even practical to say that 'people who practice the Muslim faith can self-govern.' For an American audience, I don't think that the issue of Muslim self-governance is necessarily in question. Bush is putting these ideas on the table - and commandeering the discourse in the process. These ideas, although surely existent, are quite radical anti-Muslim, White power notions. By introducing them on the presidential/CNN stage, Bush centers such notions - centrally anchoring them within mainstream debate. This to me is prescriptive and ties in with your point about designing futures. It speaks to the whole development paradigm. The problem is the idea of reinserting a racist discourse into the dominant political platform.

G: Yeah, and I think it's especially problematic when done strategically, to win an audience and to justify what the U.S. has done. So what happens is they concoct these ideas of what it is we (the invader) are doing there, and then try to justify it by saying that the people who are against occupation are backwards. So it's used as a way to justify whatever it is the US is doing in terms of the effect it has on people. This sentiment ought to be distinguished from an understanding of a people's pain, suffering and fear.

A: There's a danger, I think, in reading those comments as individual racist statements. We need to recognize the systemic implications in the American context, where that takes on a much larger significance. Who governs the US? Who governs the US in all its affairs abroad? Power is racialized in the US and this operates on a number of levels. We have to draw the connections between them.

Ok, let's move onto another quote: This is from George Bush's mom, Barbara Bush, on September 5, 2005 She said:

"What I'm hearing, which is sort of scary, is that they all want to stay in Texas. Everybody is so overwhelmed by the hospitality. And so many of the people in the [arena], you know, were underprivileged anyway, so this (laugh) this is working very well for them" (Nichols, 2005).

She's speaking about the hurricane evacuees at the Astrodome in Houston. I want to connect this to the notion of self-governance in Iraq, because in Katrina you've got, on one hand, people who were poorly situated to begin with, and who are even worse off now. According to the logic of the former first lady, these people had little to lose. So goes the thinking on Iraq Iraqis (perhaps Muslims in general) have everything to gain from western intervention and occupation - even if they don't yet know it. This is the 'we know best,' idea. I want to link that 
to the notion of anti-colonialism. We don't have to get really abstract to flesh out this idea and observe the colonial mindset of paternalism and condescension. There are two different events: one happening in Iraq, one happening in the United States, and we see the same sort of ideology put forth to form the colonial understanding and justification of each.

G: I agree and I think it is remarkable that no one's addressing these forms of paternalism and this idea of 'we know best.' Significant segments of the US expect other people to become, to take on the roles and characteristics it assigns them. People are forced to ascribe to western notions of progress and development - despite the problems that come with such pursuits. We need to subvert this. This is the whole point of decolonization: it's more than just simply looking at things in terms of a discourse, it also has to do with the way certain conversations and certain texts become commonsensical thoughts and commonsensical expressions. These need to be subverted and revealed for what they are.

A: Even if some enlightenment era discourse existed that touted free speech and western democratic forms of governance (albeit Eurocentric and universalizing in their essence) this is not what the West exports in its colonial misadventures. Britain never exported a very successful parliamentary system to any people it conquered. Britain never exported voting rights, it didn't work that way. The so-called 'best of the West' if such a thing exists, and we must problematize it if it does, stays at home in the colonial encounter. What is America in the Iraqi context? It strays pretty drastically from its rhetorical self-image at home. The US uses the very same prisons as Saddam Hussein once did to torture, rape, and murder. So, in that sense, America doesn't deliver what it's selling. When people open the box, they don't get what they bargained for.

G: Well some would disagree with you and we have to wonder where they're getting their information. A related point is the contradiction inherent in the U.S. military using force to bring about peace and democracy. This is democracy at the point of a gun. What kind of a sale involves showing the buyer your gun as you offer your wares? The transaction will be meaningless once the threat is gone - there is constant overt and non-overt resistance.

A: Absolutely. You cannot be beaten or threatened into liking a system - or believing in a particular political structure. This is at the heart of your original idea of imposition. Not only is imposition a colonizing act, it is unsustainable. Things which are forced into place have a tendency to pop back out before long.

G: The contradiction that is embedded in all of this is very problematic.

A: Yes, they're uninvited and are occupying by force - doing very little for democracy.

Let's go back to the instance of Katrina and the domestic context of the United States. Here's a quote from senior CNN correspondent Wolf Blitzer: "You simply get chills every time you see these poor individuals," he's talking about post-Katrina New Orleans. He continues:

"as Jack Cafferty just pointed out, so tragically, so many of these people, almost all of them that we see are so poor and they are so Black, and this is going to raise a lot of questions for people who are watching this story unfold" (“Aftermath," 2005).

This is clearly a controversial statement. What does it mean for something to be "so Black"? We have on one hand in the United States, a lack of conversation about race - a deafening silence, and on the other hand we have different levels of commentary. From the cryptic, like Mr. Blitzer, to the overt from people like Kanye West saying, "George Bush doesn't care about Black people" (de Moraes, 2005). Alongside a somewhat bold critique from a pop 
star, we have mainstream news implying that tragedy, poverty and disenfranchisement seem to be characteristics of Blackness. How do you respond to this?

G: It's how we read Blackness. In this case, it's equated with these notions about poverty and the other troubling ideas expressed here. I think it is crucial that we speak about resistance and further, that we speak about the possibilities of agency. So when we process these images and texts about hapless people, designed for public consumption and to elicit the paternalistic empathy of the audience, we must keep our gaze on resistance. The mainstream media talks about how we need to help these poor, downtrodden folks but there's no attempt to connect this discussion to how people are struggling or finding ways to support themselves.

A: Well, when they do that they're looters of course.

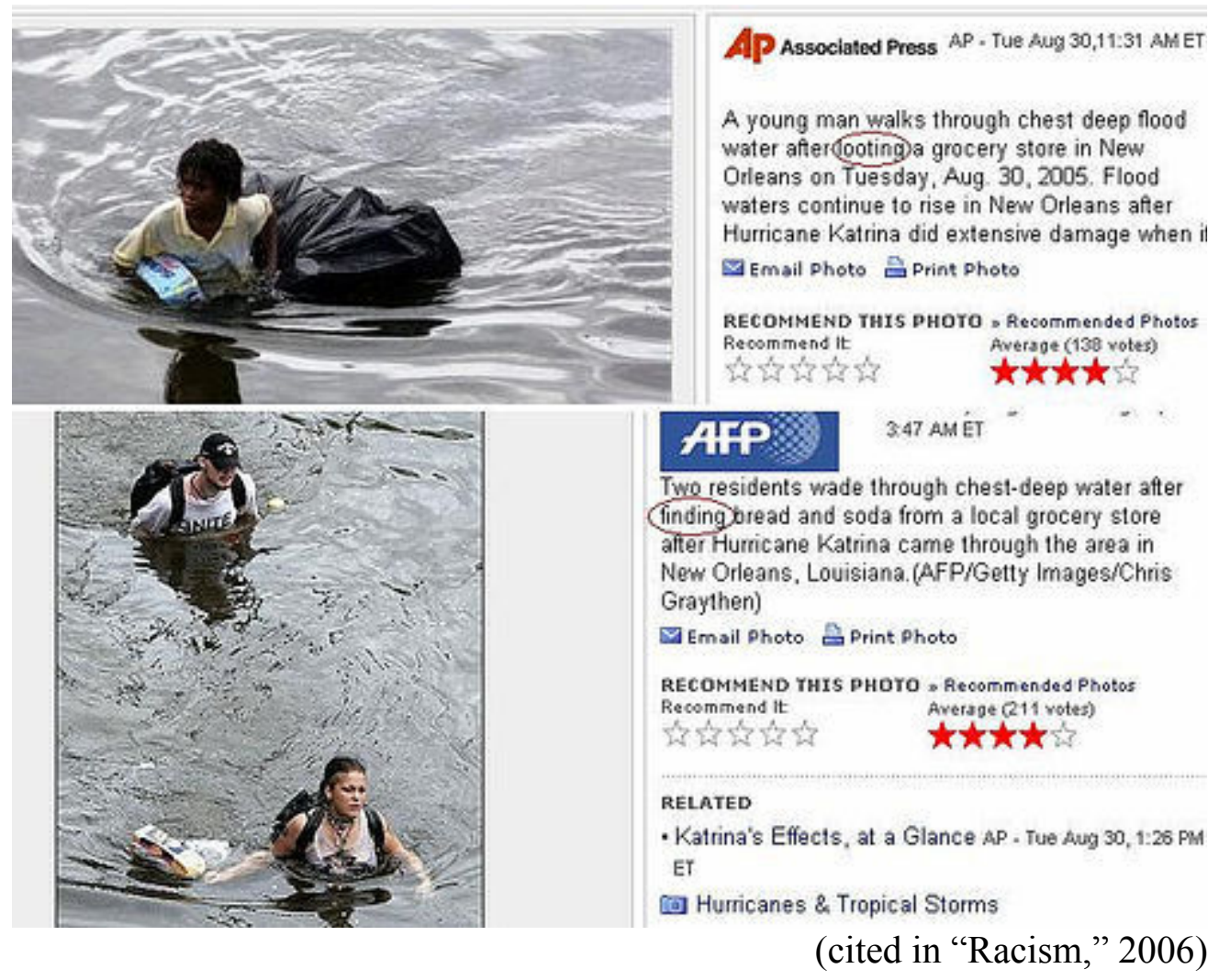

G: Right. As many have mentioned sarcastically (and not so sarcastically) when Black folks break into a store, they 'loot' food while Whites doing the same simply 'find' food.

A: Finders keepers, looters weepers. Maybe George Bush is right when he says the hurricane did not discriminate; but the media certainly did. Let me give you another quote before we return to Mr. Bush. This is from BBC correspondent Matt Frei, on October $2^{\text {nd. }}, 2005$. He reports:

"The battle between nature and man is almost over, but the battle between man and man is just beginning. The scene here is more Africa than America. From the air, the destruction is humbling. Luxury yachts thrown about like toys. Looking closer, there's stagnant, dirty water, and then there are the survivors, mostly poor, black and angry. You see dead bodies here, as you wander around the streets" (Frei, 2005). 
Now that statement is problematic for a number of reasons. How do you respond to this sort of old school colonial racism?

G: This is again, the attempt to deny the basic humanity of African peoples. Powerfully, it is couched in a hollow empathy for the people and their suffering. There's a way you can present the story without denying the basic humanity of the people. We must ask why such an approach is not taken. For some of us, our rage comes in an attempt to restore that basic humanity. We need answers to these questions.

A: Ok. To come back to the idea of competing truths and to epistemic hegemony, George Bush, in a number of different interviews, has denied the racial element of the Katrina relief efforts. The Guardian writes,

"United States President George Bush denied on Monday that there was any racial component to people being left behind after Hurricane Katrina, despite suggestions from some critics that the response would have been quicker if so many of the victims hadn't been poor and black, he said that the hurricane didn't discriminate and neither did the rescue effort" (Loven, 2005).

This speaks to the idea of selected and unselected truths: selected truths are those that can exist and unselected are of course those that cannot. This results in outright denials of what's happening and what might happen. In other words, not only is our reading of the present controlled, our imagining of the future is at stake as well. We have to start thinking about new truths and about taking control of these epistemic moments.

G: Right, talking about new truths is key. We also know that, even before hurricane Katrina, there were sufficient warnings, and so it makes you wonder how come these warnings were not heeded? What were the reasons behind the silence and inaction?

A: There weren't only warnings about levees breaking. There was also rampant economic and racial inequality before Katrina hit. New Orleans was a walking social disaster of human inequality and exploitation long before Katrina blew onto Louisiana's shores.

\section{Section Four - Australia and France on Fire}

I'd like to talk about Australia and what's been happening there recently. The following is from the Sydney Morning Herald, from December $12^{\text {th }}, 2005$ :

"[A] bare-chested youth in quicksilver board shorts tore the headscarf off the girl's head as she slithered down the Cronulla dune, seeking safety on the beach from the thousandstrong baying mob. Up the road, Marcus 'Carcass' Butcher, 28, a builder from Penriff, wearing work boots, wore camouflage shorts and a black singlet bearing the words, 'Mohammed was a camel-fucking faggot,' raised both arms to the sky, 'fuck off 'Lebs,' he cried victoriously. It was one last act of cowardly violence on a sad and shameful day that began as a beach party celebrating a kind of perverted nationalism that was gatecrashed by racism. A crowd of at least 5,000, overwhelmingly under 25, took to Cronulla's shore and beach-side streets. Police were powerless as 200 -odd ringleaders, many clutching bottles and cans of beer, and smoking marijuana, led assaults on individuals and small groups of Lebanese-Australians who risked an appearance during the six-hour protest. Cronulla has long been the scene of battles with outsiders. The 
early 1960's saw pitched fights between so-called Westies and so-called Surfees. Then, the media portrayed them as wars between teenage subcultures, but they always had an economic, if not class, element to them. It was a time when the White Australia policy still existed and nobody thought it was based on racism" (Murphy, 2005).

So as racial violence exploded on the famous beach, Australian Prime Minister, John Howard "called the violence sickening, but denied that it was underpinned by a vein of racism running through Australian society" ("Cars, Windows," 2005). He went on to say, "I do not accept that there is underlying racism in this country" (ibid). I want to draw a link between that and what Bush said when he denied there was a racial element to the response to Katrina. This goes beyond contradiction of plain fact. It seems the more race and other sites of oppression enter popular discourse, the harder the mainstream fights to keep an open discussion of oppression off the table. Although these various quotes express fairly extremist ideologies, they have not been taken up as such, they haven't been seen as extreme things in the popular media. In other words, these constitute mainstream responses. When we talk about the need to investigate silences, we're countering a major theme, a very large and dominant force. I don't know if you followed much that's happened in Australia, but would you care to comment?

G: To fight racism we must take responsibility for racism: it is as simple as that. I think denials come about in order to reinforce particular ways of knowing. We need to interrogate the denial of race. Bringing in a racial critique subverts complacency. It subverts dominant understandings of what Australian society is; this is to say notions of a race-free or non-racial society. There is necessarily an official denial, which is couched in a way that aims to demonstrate a certain benevolence of the state.

A: Precisely, yeah. So how does an anti-colonial response challenge these markers of epistemological hegemony?

G: It challenges them by bringing the voices of the subordinated, the voices of the oppressed by reassuring their ontological existence and epistemological positions. The question is, what do those who are engaging in the rioting, those bodies who are actually very upset about what is going on, how would they characterize what they were doing? They would identity race. Oppressed people can almost always identify their own disenfranchisement, be it race or class based. So again, what the anti-colonial does, is bring the power of the subordinate voice to challenge the dominant. They have their own understanding of what is happening to them; their own completely legitimate interpretation.

A: How do you get around, in the educational context, the tokenization and binary making tendency of competing perspectives and narratives? In other words, how do you avoid the liberal tendency to bury concrete understandings in the grey area between black and white - how do we get past simplistic two-sided analyses?

G: It's a difficult task and knowledge is crucial for its resolution. One of the anti-colonial prisms is that the voice of the oppressed is intrinsically valuable. They have experienced the situation, and are thus speaking from experiential knowledge. There must be some legitimacy placed on that voice. It cannot be dismissed. Further, that voice cannot simply be put in the same zone as just any other voices. This voice is not simply one of many. The experience of oppression positions one to know differently, and that knowing means there is an epistemic saliency to that voice. This does not mean the oppressed always knows best though.

A: So this is where anti-colonialism takes up the notion of epistemic saliency. Going back to the ideas of duality of complexity, this may get complicated when certain people have a salient 
voice on one issue, but maybe not on another, which isn't to say it's problematic, but challenging. From a teaching perspective we have to really ensure that we don't just slip into one perspective against another, against another, and so on.

G: I think the anti-colonial teacher has to talk about history. We have to understand and promote understanding of the way certain voices have become dominant, and how certain voices have become devalued, or subordinated. What are the processes and consequences of that subordination? We must look at how certain knowledges, or certain ideas have become dominant as well as how they are being used and not questioned. It is very important to bring forth the subordinated voice to subvert and challenge what is taken for granted, what is seen as normal, what is accepted as the conventional norm.

A: So we can construct an anti-colonial model for reading events, or reading history. We can take the dominant story and then start intentionally, in a linear fashion, and say we're going to look to the voices of the oppressed in this situation. How might we flesh this out in an educational context?

G: We would take it from a historical perspective right? We would need to look back at the specific ways in which dominant voices become dominant. What are the processes of evaluation, legitimation and accreditation in the educational context that assign value to certain voices? Who speaks for whom and how? What voices are absent? Why are they absent? These questions need to be asked. How do we bring these voices into the conversation to challenge and subvert normative hegemony?

A: Exactly, not just as additional voices, but as a counter force. This necessarily involves students. Students have to engage their own social and epistemological locations, the parameters of their positions and the ways they can find power in and out of the classroom.

There are some key philosophical tenets of anti-colonial theory: for instance, the idea that subversion of colonial and colonizing relations lies at the heart of resistance in this context. So, in order to reveal the relations between and among colonizer and colonized, we must interrogate connections between the self and the other. What do these statements tell us about colonial relations and the state of empire in 2006? What is the state of empire in 2006 ?

G: I think that colonial relations have become more complex, more sophisticated. Dominant language and discourse are used very powerfully to reify, and to make commonsensical, certain truths. Within this discourse is the assertion of a false neutrality and innocence of the dominant. Within this presentation of the dominant trope is an embedded sense of virtuousness, a sense that the dominant is in no way implicated, and that the dominant is in no way an accomplice in the making of the problems about which the subjugated seem to be always complaining.

A: There are definitely those among the dominant who think they are not responsible. On the other hand, what about the increasing number of Christian fundamentalists in the United States for example, who seek to be responsible - to make change, using a language of war and aggression? What about those who seek the active (rather than false passive) position, and who wish to intentionally reshape society in terms of hard-edged notions of right and wrong? Are we in a much different place than we were ten years ago?

G: No. It's more of the sophistication that I spoke about. Even when we speak of the New Right, let's remember that everything they do is in keeping with an agenda. I think it's a total agenda, it's well planned and it's based on an ideology. The right espouses this, but denies the sociopolitical underpinnings as well as the true intentions of the project. To me it is sophistication that camouflages their message. So sometimes, without bringing a critical reading, one can easily fall into the trap and work with some of their ideas. It comes back to the question of political and 
intellectual sophistication. One of the goals of anti-colonial thought is to uncover the political and intellectual interests operating in the colonial encounter.

A: We have to look at that encounter on a number of levels. Within anti-racism, we look at oppression as identified and separated into individual, institutional and systemic forms. So, in what ways are these delineations necessary when understanding other forms of struggles; like anti-colonialism for instance? How can such delineations be useful in understanding and deconstructing the colonial underpinnings of the events in New Orleans, Sydney and finally, the suburbs of Paris? You've addressed this to a certain degree in talking about the sophistication of media. Is this hard to break down further?

G: Yeah, it's hard to break down, but that's what anti-colonialism should be doing, right? For example, the individual level is how people most intimately understand the issues. This is how individual subjects understand what is going on. So, we break it down on that level! And then, how are institutions complicit in the making of the problem? By the same token, how do institutions become a site for change? So we break it down along these lines. And then, of course, we talk about a system and the systemic dimensions of social relations. One example obviously, is systemic neglect. I should also mention that incidents of oppression are rarely isolated. Internally, individual, institutional and systemic incidents of oppression are fundamentally related. Externally, these issues are connected to issues of education, issues of law, issues of policing and issues of authority. From there, we consider the global or transnational dimensions and say, "hey, look at the events in Australia, in France, in North America. They all have certain things in common." Again, it relates to people beginning to speak up about the extent of systemic neglect, racism, economic oppression and social exclusion. A: Well that ties nicely to ideas of intersectionality. Can you discuss the ideas of interlocking and intersecting sites of oppression? The example of the beach in Australia is interesting. It points to the fact that certain locations lend themselves to conflict. One article mentions that over thirty years ago, class battles raged on that very sand. Are there spaces, not necessarily just physical, that are better suited as sites of conflict than others? If so, how do we go about transforming those spaces?

G: Right. I'll take the latter one. While I think certain spaces are better suited for conflict than others, any space in which a level of power has been invoked to disenfranchise a segment of the community, we'll see conflicts arise. In other words, in those spaces where we haven't had time to talk about the inequity that exists, or to talk about how these inequities are reproduced continually by individual and institutional support mechanisms, we're more likely to see conflict. The level at which people are intellectually aware and able to identify the processes operating around them also affects the likelihood of conflict. These things are rather important for how we come together to think about conflict. In order to fully recognize why there's conflict, one has to have the intellectual skills to articulate it.

A: So, intersectionality can be understood, particularly within anti-colonialism, as something that informs a holistic gaze?

G: Yes, exactly. Also, this is something that implicates everyone.

A: Yeah. That's where I see it veering off from your version of anti-racism, which I understand might be changing at the moment. We need to work with these things to better inform social change. In that sense, we can see that overlapping space as a good place to start mobilizing and building resistance, in working with difference across different types of oppression to effect positive change. 
G: People can understand colonial relations from a variety of different positions and become linked to one another in different ways. So, to me, because people necessarily come at it from varied angles and positions, we must work with this variety and difference to build community. A: Working with an individual starting point has its implications though. If we take this idea of an entry point, we have to make sure that it's not just an entry point; it has to be a starting point from which you begin to work with other subject locations. Also, for all of our talk on sites of oppression, I think we have to look at inverse notions of privilege; White privilege in particular, as well as male privilege and heterosexism. We cannot allow this inverse understanding of things to get lost.

G: Well privilege and oppression go hand in hand. And if privilege and oppression go hand in hand, we must also understand that when bodies engage in social movement politics, there's a space where we bring privilege, and that privilege is useful in helping us to transform. It's a question of what we do with our identities. I grew up with an African teaching that says "It's not what one is called, it's what one responds to that is most important." What is most important is that with all of these identities and identifications, we decide to engage politically and work to bring about change; these are the great challenges.

A: Absolutely, and I guess the freedom to have that kind of decision comes with the responsibility of having that privilege. That's why there has to be an element of accountability, where, if you do have that privilege and you do come through that door, it is incumbent upon you to use that in an anti-colonial way. Otherwise one is not really engaging with the ideas of privilege and oppression.

G: In many ways, it's very important in the Foucaultian sense, to talk about power relations; power is relational. But you also have to go beyond that to say that while power is relational, there are multiple and simultaneous sites of power. But we should also talk about how certain bodies are better positioned to address these issues given the privileges that come with certain identities. We have to talk about that. If you want to address accountability and work towards resistance, you have to talk about different responsibilities and obligations that are placed on us by virtue of history, by virtue of our identities, by virtue of our location and by virtue of our subject positions.

A: And it must be a reflexive and normative look at those obligations; for instance the responsibility of Whites to subvert White privilege. We cannot keep our privilege or our responsibilities in our pockets.

I want to return to the quote about the Astrodome: the one about being "more Africa than America". For me this is a very important articulation, in two ways: one is the obvious implication of 'civilized America' and 'savage Africa'. Although it's usually there, this racist message usually finds more subtle expression in mainstream media. The other is the implicit denial, within the statement, of just what America is for many people living there. Present is the idea that America cannot be like this. America, of course, is like this: it's racist, it's classist, it's sexist; and it's got the thinnest of veils protecting some rights for some people, some of the time. Despite this, Africa is engaged here as the 'other'. So while Cuba successfully dealt with the same hurricane and offered aid to poor Americans, along with Venezuela's Hugo Chavez; the grand narrative (that this cannot happen in the United States) seems to live on, and seems to live on at the expense of the racialized bodies in the US. It lives on in the articulation of racist notions of Africa, as a whole. How do we rupture these narratives? If you were in a classroom right now, how would you tackle it? 
G: Africa is not stuck somewhere waiting for us to modify our thoughts. I think we need to talk about the making of this sense of complacency. It doesn't really allow us to trouble dominant characterizations of what is happening. There is a helplessness in the idea that 'this shouldn't be happening to us because this is America' or because 'this is Canada'. To me, in the anti-colonial sense, we really need to talk about the embedded inequities and the embedded uses of power. In other words, nothing should be taken for granted; we cannot afford the expense of complacency. This is what anti-colonial thought brings to the discussion, a pedagogical subversion.

A: We also have to make connections. For instance, how do you connect a racist or a classist joke to what's happening in Iraq? How do we draw those broad connections using the micro to affect the macro; using the macro to implicate and hold accountable people in the micro elite? The notion of empire is useful here because it operates on at least two levels at all times. Internally we have the programmatic socialization around insider and outsider groups - looters and finders. Externally we have the civilizing mission, which combines economic exploitation with cultural imposition - heroes and terrorists. The US is not just saving Iraqis from Hussein; the US is saving the Arab man from himself. So we have production in both the metropolis on one hand (the invaders have to come from somewhere and it certainly won't be from the ranks of the ruling class) and in the periphery on the other hand (as the missions in Iraq and elsewhere roll on).

Can we move on and discuss France?

G: Sure. I think we may not get to everything we intended to discuss.

A: The story out of France in the autumn of 2005 was the uprising in the Parisian suburbs of French youth, many of whom were African. After the death of two teenagers at the hands of French police, thousands of people took to the streets for days on end. The protests grew and spread to other countries. What I'd like to look at first is the state response to these uprisings. One striking occurrence came when interior minister Nicolas Sarkozy resurrected a law first passed in 1955, (one year after the Algerian Revolution started) designed for the Algerian colonial context as a control mechanism. It was immediately invoked in the Parisian suburbs against the so-called rioters. Following the uprisings, the interior minister arranged the deportation of ten of the so-called 'rioters' ("France MP's," 2005). I've got a couple of questions and thoughts here. First of all, do we see these as spontaneous riots, or do we see them as a very systematic response to very systemic oppression? How do we read the responses by French youth? The uprising was basically well organized: there were very few people killed, the youth didn't kill each other, the youth didn't burn working class homes, the youth burned mainly nice cars, and the youth took aim only at the enforcers. Do we see this as an act of anticolonialism?

G: Like you say, they knew what they were doing; they knew what the targets ought to be. And that, to me, speaks volumes. Here is a moment wherein people reflected on their past and present, and decided to act in a way that was indicative of some sort of rhythm, demonstrating some sort of methodological planning. I think it's very interesting that it spread so quickly. This demonstrates the degree to which it resonated with other racialized and marginalized Europeans. Now the question you're asking is: should we see this as a form of anti-colonialism? We most definitely should see it as a form of anti-colonialism, because resistance is a key component of anti-colonialism. They were resisting imposition, exclusion and marginality. You cannot have anti-colonial discourse or practice that doesn't talk about resistance. What we were seeing there were groups of youths resisting long-standing deprivation and systemic neglect. So it was a form of resistance. In many ways I see it as the violence of systemic neglect running up against 
violence of a more simplistic nature, which involved people expressing their concern and anger about what has happened to them through history, through time. They clearly needed to call attention to that in order for it to be addressed. To inform an anti-colonial pedagogy, we must look at: how such resistance is organized, how it is expressed, how people are called upon to respond, and what the obligations and responsibilities are that this kind of insurgency calls up.

A: Also, in order to fully see another side of the discourse, we must look at the political response of the state. Earlier, Sarkozy said that the suburban community in which the uprisings started needed to be "hosed down with a pressure washer." He called the rioters "scum" and "thugs" (Rotella, 2005). We can juxtapose this with the Republican senator from the United States, who said, "We finally cleaned up public housing in New Orleans. We couldn't do it, but God did," in reference to Katrina (Babington, 2005). So I think you get this notion of the divine, dominant power, and it's this colonial language, the holy colonial, that you see in a really powerful way in both contexts.

G: What we also see in France is that when all these things were going on, there was an interplay between the state's oppressive force and the protestors' actions - the people also waited for the response of the state, and were spurred on further in response to state force. That's why it took so long to put this thing down. If an incident such as this draws out racist or classist commentary from dominant French citizens, then these marginalized people become further convinced of the legitimacy of their struggle.

A: So we watch and resist.

We have to wrap up shortly. Can we return to the theoretical and practical elements of anti-colonialism and education?

G: Yeah, I'd like to address a couple of things. One is that when we talk about the anti-colonial, we also have to look at how we talk about the colonial in the transnational/global context. To participate in anti-colonial education we have to think in terms of school and education in different parts of the globe. For example, in my opinion, there's a special anti-colonial practice needed in the African schooling system. It's necessary not simply to challenge the dominant subject matter, but also to challenge the denigration and devaluation of local culture, local experiences and knowledge of self. The way these have been taken up in discourse becomes critical in the anti-colonial framework. To me, anti-colonialism should help us re-vision what constitutes, or what should constitute education. Education cannot simply be knowledge for the sake of knowledge. Education must compel action. Education must speak to people's lived experiences; and above all equip people to transform their present conditions and situations. This is why the practical edge of anti-colonialism is critical. It cannot be presented simply as theory; there must be a practice to it. If you look at some of the early anti-colonial struggles, there was a whole, shall I say, method to the pursuit of that struggle.

A: Can you give an example?

G: Che Guevara's writing (Deutchmann, 1997).

A: Yeah, absolutely.

G: Right, he talks about some of the methods of guerilla warfare. He bridges the divide between theory and practice, between theory and action. In the classroom setting, we can prepare our students to be able to challenge some of the commonsense, everyday, taken for granted assumptions that constitute the epistemological element of colonialism.

A: We must teach our students to become revolutionaries?

G: Exactly. And I don't think being a revolutionary means just shedding blood. You have to look at it in terms of the multiple modes and functions of revolution. We also have to consider 
the issue of accountability; accountability not just to the learners, but also to communities that sustain the school and the educational system. This means that teachers and administrators work with and for students, parents and the community as a whole.

Above all, when we talk about anti-colonialism we also talk about how we look at the western academy and issues of knowledge production, interrogation, validation and dissemination. Part of the practice of the western academy is the reproduction of colonial relations, whether in the text, in classroom relations or in the way certain bodies are validated and invalidated. We have to look at these sites and target the processes by which these colonial relations are continually reproduced. It is critical that the classroom be a decolonized space.

A: It needs to be a decolonizing space, as well as a decolonized space. Anti-colonialism must be something we do, not say. This can begin with the process of self-location and trying to engage with embodied knowledge.

G: Yeah, I agree. But decolonization also must deal with recognizing responsibility. The question of responsibility, I think, is sometimes misused. Responsibility is used to blame and pathologize. For example, can we talk about individual responsibility? Of course we can talk about individual responsibility.

A: But not in a neo-liberal sense.

G: Right.

A: I think we need to talk about responsibility in place of the idea of rights. When we invoke a rights discourse, a trickle down system usually follows, wherein rights really end up as exclusive privileges for a small number. If we take it from a different angle, we can talk about communal responsibilities, and thus accountability.

G: Yeah, for example, we cannot simply present our youth with moral imperatives on responsibility, without talking about the resources, the skills, and the tools that allow the youth to be responsible. We need to be accountable individually to our youth. We also need to talk about the state; it cannot, on the one hand, call on youth to be responsible, while on the other hand, shirk its own responsibilities to the youth.

A: And you have to empower people enough to hold others accountable. For example, certain communities in Canada do hold their schools very accountable, and those communities are often White, very affluent and possess a sense of entitlement: even though technically speaking, legally speaking, there's a guaranteed equality of access to education in Canada. This equality is a myth of course and a question of agency emerges when we look at who has the power to hold others accountable.

G: Right. I think at the end of the day, we have to talk about the future. I think that the future is being contested; when we look at our classrooms and the discursive practices therein, we identify the contestations of the future. We must use our creativity and our resourcefulness to imagine new possibilities, a new future, and new ways to let our learners recreate a vision. A critical part of anti-colonial practice is how we give them that space to imagine the future and their centrality therein.

A: So moving away from the notion of the colonizer designing futures for others, anticolonialism shifts the gaze to empower people in designing futures of our own; an organic realization of our world and our place in it.

Thank you. 


\section{Post Script: Anti-Colonialism and the Classroom}

It is crucial that we address and interrogate colonizing relations in our schools. This means fighting oppression in terms of its multifarious and complex dimensions, while identifying the ways colonial relations play a role in every sphere of school life (e.g., knowledge production, interrogation and validation). Anti-colonialism provides lessons for teachers and students. For those against whom education has been used as a weapon and as a tool of dispossession, anti-colonialism calls for the invocation of one's past and thus one's place within the present and future (Dei and Kempf, 2006). The dialogue above points not only to the theatrical elements of socio-political systems of oppression, but also to local realities and the individual damage suffered as a result of our ongoing colonial epoch. It is incumbent upon the pedagogue to bring these two material and discursive realities together in the classroom. Working with the epistemological, ontological and axiological contributions and capabilities which all students bring to class, teachers must de-colonize their teaching. This means challenging their own subject positions and questioning the degree to which they may themselves be implicated in the oppression they seek to undo. Education is a living and breathing thing that goes where the teacher tells it to go, and does what the teacher tells it to do. With this power comes a responsibility to the student, the community and society as a whole. The anticolonial teacher is accountable to the values established by and for the community he serves. The anti-colonial teacher is responsible for transforming the world she finds before her. Most importantly, the anti-colonial teacher is responsible for the decolonization of her students and herself. 


\section{References}

Aftermath of Hurricane Katrina; New Orleans mayor pleads for help; race and class affecting the crisis? (2005, September 1). The Situation Room. Retrieved from http://transcripts.cnn.com/TRANSCRIPTS/0509/01/sitroom.02.html on May 29, 2006.

Anderson, B. (1991). Imagined Communities: Reflections on the Origin and Spread of Nationalism. London \& NY: Verso.

Babington, C. (2005, September 10). Some GOP legislators hit jarring notes in addressing Katrina.The Washington Post, p. A04.

Bon Jovi stuns Oprah with $\$ 1$ million donation. (2005, September 22). Retrieved from http://www.contactmusic.com/new/xmlfeed.nsf/mndwebpages/bon $\% 20$ jovi\%20stuns $\% 20$ oprah\%20with\%20\$1\%20million\%20donation on September 22, 2005.

Cars, windows smashed in Sydney race riots. (2005, December 13). CNN. Retrieved from http:/www.cnn.com/2005/WORLD/asiapcf/12/12/australia.racial.unrest.ap/ on December 19, 2005.

De Moraes, L. (2005, September 3). Kanye West's Torrent of Criticism, Live on NBC. The Washington Post, C01.

Dei, G. J. S. (2000). Rethinking the Role of Indigenous Knowledges in the Academy. International Journal of Inclusive Education. 4(2): 111-132.

Dei, G. J. S . and Asgharzadeh, A. (2001). The Power of Social Theory: Towards an AntiColonial Discursive Framework. Journal of Educational Thought. 35(3): 297-323.

Dei, G.J.S., and Kempf, A. (Eds.) (2006). Anti-Colonialism and Education: The Politics of Resistance. Rotterdam: Sense Publishers.

Deutchmann, D. (Ed.) (1997). Che Guevara Reader. New York: Ocean Press.

Du Bois, W.E.B. (1997). On the Souls of Black Folks. Boston: Bedford Books.

Dyer, R. (1997). White. London: Routledge.

Fanon, F. (1969). Black Skin, White Masks. New York: Grove Press.

France MPs back emergency powers. (November 15, 2005). BBC News Europe. Retrieved from news.bbc.co.uk/2/hi/europe/4437800.stm on December 19, 2005.

Frei, M. (2005, September 2). Reporter's Log: Katrina's Aftermath. BBC World. Retrieved from http://news.bbc.co.uk/1/hi/world/americas/4203890.stm on May 29, 2006.

Loven, J. (2005, September 12). Bush Denies Racism in Katrina Response. Mail and Guardian. Retrieved from http://www.mg.co.za/articlePage.aspx?articleid=250733\&area=/breaking_news/breaking _news_international_news/ on May 29, 2006.

May, S. (Ed.) (1999). Critical Multiculturalism: Rethinking Multicultural and Anti-Racist Education. London: Falmer Press.

Memmi, A. (1969). The Colonizer and the Colonized. Boston: Beacon Press.

Murphy, D. (2005, December 12). Thugs Ruled the Streets, and the Mob Sang Waltzing Matilda. Sydney Morning Herald. Retrieved from http://www.smh.com.au/news/national/the-mobsang-waltzing-matilda/2005/12/11/1134235951620.html on May 29, 2006.

Nichols, J. (2005, September 8). The Roots Of Bush's 'Compassion'. CBS News. Retrieved from http:/www.cbsnews.com/stories/2005/09/06/opinion/main821528.shtml on May 29, 2006.

Racism. (2006). Flickr. Retrieved from www.flickr.com/photos/firewall/38725768/ on May 23, 2006. 
Rotella, S. (2005, November 7). Chirac Vows to Restore Order as Riots Grow Across France. Los Angeles Times. Retrieved from LosAngelesTimes.Com on December 19, 2005.

Said, E. (1993). Culture and Imperialism. New York: Vintage Books.

Spivak, G. C. (1999). A Critique of Postcolonial Reason: Toward a History of the Vanishing Present. Harvard University Press: Cambridge, Massachusetts.

Whitehouse Website. (2004, April 30). Joint press conference. Retrieved from http://www.whitehouse.gov/news/releases/2004/04/20040430-2.html on December 19, 2005. 